\author{
Notaike \\ e-ISSN: 2655-9404 \\ p-ISSN: 2721-8376 \\ Vol. 3 No. 3, Oktober 2020 \\ DOI: $10.20473 /$ ntr.v3i3.22832
}

Article history: Submitted 5 August 2020; Accepted 2 September 2020; Available online 1 October 2020

\title{
Tinjauan Yuridis Pembangunan Perumahan Di Atas Gedung Bertingkat (Studi Kasus Cosmo Park Townhouse Jakarta)
}

\author{
Malikuz Zahir \\ malikuzzahir89@gmail.com \\ Universitas Airlangga
}

\begin{abstract}
The necessity of house and residences that is increasingly high makes the investor develop establishtment of an apartement/flat with an advanced facilties to gain as many as possible purchases from the urban people. One of those advanced apartment/flat located at Central Jakarta, namely Cosmo Park Townhouse, a residence that is established on the rooftop of Thamrin City Mall. The establishtment of that kind of residences causes an antinomy to the law provisons, spesifically about the ownership titles of the land/the building of each house units at Cosmo Park Townhouse. The ownership titles in this case could referring to The Rights of The Land which defined on Article 43 verse (1) Law Number 1 of 2011 about Houses and Residence juncto Article 16 verse (1) Law Number 5 of 1960 about Basic Rules of Agrarian Principles, or refeering to The Strata Titles which defined on Article 46 verse (1) Law Number 20 of 2011 about Flat. The antinomy between two kinds of ownership titles could generate the rights of the people became unprotected, because there is not legal certainty about authority, obligation, and prohibition for the resident of Cosmo Park Townhouse to commit or to not commit on their house units.

Keywords: Residence; Extent Buliding; Ownership Titles; Legal Certainty.
\end{abstract}

\footnotetext{
Abstrak

Meningkatya kebutuhan rumah mendorong para investor untuk mengembangkan pembangunan rumah susun berfasilitas lengkap guna menarik minat pembeli yang sebanyak-banyaknya, salah satunya yaitu Cosmo Park Townhouse, sebuah kawasan perumahan yang berdiri di atas atap gedung bertingkat Mall Thamrin City Jakarta Pusat. Pembangunan perumahan di atas gedung bertingkat yang demikian menimbulkan antinomi/pertentangan ketentuan hukum terhadap status penguasaan atas tanah dan/ atau bangunan masing-masing unit rumahnya, yang dalam hal ini dapat menggunakan Hak Atas Tanah yang tercantum dalam Pasal 43 ayat (1) Undang-Undang Nomor 1 Tahun 2011 Tentang Perumahan dan Kawasan Permukiman juncto Pasal 16 ayat (1) Undang-Undang Nomor 5 Tahun 1960 Tentang Peraturan Dasar Pokok-Pokok Agraria, atau menggunakan Hak Milik Atas Satuan Rumah Susun dalam Pasal 46 ayat (1) Undang-Undang Nomor 20 Tahun 2011 Tentang Rumah Susun. Antinomi tersebut pada akhirnya akan berakibat pada tidak adanya perlindungan hak-hak masyarakat berupa kepastian hukum atas serangkaian wewenang, kewajiban, dan larangan bagi penghuni untuk berbuat atau tidak berbuat sesuatu terhadap unit rumah Cosmo Park Townhouse.
}

Kata Kunci: Perumahan; Gedung Bertingkat; Status Penguasaan; Kepastian Hukum. 


\section{Pendahuluan}

Bagi manusia, rumah sebagai tempat tinggal merupakan kebutuhan dasar (basic need), selain kebutuhannya akan makanan dan pakaian. Rumah juga merupakan tempat dimana berlangsung proses sosialisasi pada saat seorang individu diperkenalkan kepada norma dan adat kebiasaan yang berlaku di masyarakat sehingga kondisi tempat tinggal seseorang akan berpengaruh pada pembentukan watak-kepribadian, keterampilan, dan wawasannya di kemudian hari. Oleh karena fungsinya yang begitu vital, maka negara menjamin bagi setiap orang berhak hidup sejahtera lahir dan batin, bertempat tinggal, dan mendapatkan lingkungan hidup yang baik dan sehat sebagaimana tercantum dalam Pasal 28 huruf $\mathrm{H}$ ayat (1) Undang-Undang Dasar Negara Republik Indoenesia Tahun 1945 (selanjutnya disebut UUD NRI 1945). Selanjutnya, sebagai dasar hukum, kebijakan, arahan, dan pedoman untuk memenuhi kebutuhan tempat tinggal masyarakat terutama bagi mereka yang berpenghasilan rendah, diundangkanlah Undang-Undang Nomor 1 Tahun 2011 Tentang Perumahan dan Kawasan Permukiman (UU Perumahan). Penyelenggaraan perumahan dan kawasan permukiman dalam UU Perumahan secara garis besar bertujuan untuk penyediaan dan kemudahan perolehan rumah. ${ }^{1}$ Namun kemudahan yang dicita-citakan tersebut terhambat dengan masalah kependudukan, seperti jumlah penduduk, laju pertumbuhannya, dan perubahan rata-rata jumlah jiwa keluarga yang umumnya terjadi pada kota-kota besar. ${ }^{2}$

Sebagai contoh adalah provinsi Daerah Khusus Ibukota Jakarta yang dihuni oleh 10.374.235 jiwa, dengan wilayah daratan berdasarkan Surat Keputusan Gubernur DKI Jakarta Nomor 171 tahun 2007, hanya seluas $662,33 \mathrm{~km}^{2}$. Itu artinya pada setiap $1 \mathrm{~km} 2$ wilayah darat DKI Jakarta, dihuni sebanyak 15.367 jiwa. $^{3}$ Peyediaan perumahan dan kawasan permukiman menjadi sulit karena jumlah penduduk yang meningkat bertolak belakang dengan luas tanah -sebagai alas

\footnotetext{
1 Penjelasan Umum Undang-Undang Nomor 1 Tahun 2011 Tentang Perumahan Dan Kawasan Permukiman.

2 Erny Suciapriyanti, Tinjauan Yuridis Pemberlakuan Undang-Undang Nomor 20 Tahun 2011 Tentang Rumah Susun Terhadap Semua Bangunan Bertingkat, Skripsi (Universitas Sumatera Utara 2012).[2].

3 Badan Pusat Statistik Provinsi DKI Jakarta, Jakarta Dalam Angka (2019).[69].
} 
pendirian bangunan- yang semakin menurun ketersediannya. Untuk mengatasi hal tersebut, diperlukan sebuah tempat yang tanahnya sempit namun dapat menampung banyak orang, sehingga pada akhirnya mendorong perubahan pola/ bentuk hunian masyarakat, yang awalnya dibangun secara horizontal menjadi dibangun secara vertikal, yaitu dalam bentuk rumah susun. Pengaturan mengenai rumah susun terwujud dalam adalah Undang-Undang Nomor 20 Tahun 2011 Tentang Rumah Susun (untuk selanjutnya disebut UU RuMAH Susun). Sebagai amanat dari Pasal 46 UU Perumahan yang berbunyi:" "Ketentuan mengenai rumah susun diatur tersendiri dengan undang-undang".

UU Rumah Susun seyogianya menjadi pedoman hukum penyelenggaraan hunian bagi masyarakat secara kolektif berdasarkan asas-asas: ${ }^{5}$ kesejahteraan, keadilan dan pemerataan, kenasionalan, keterjangkauan dan kemudahan, keefisienan dan kemanfaatan, kemandirian dan kebersamaan, kemitraan, keserasian dan keseimbangan, keterpaduan, kesehatan, kelestarian dan berkelanjutan, keselamatan, kenyamanan dan kemudahan, serta keamanan dan ketertiban. Asas-asas yang demikian ditujukan agar fungsi kontrol oleh Pemerintah terhadap pengembang yang menyelenggarakan pembangunan Rumah Susun di kota besar dapat dijalankan, mengingat dewasa ini telah banyak dibangun rumah susun di kota-kota pusat perindustrian. Sebagai contoh, di provinsi DKI Jakarta, terdapat 304 blok rumah susun yang tersebar pada 49 lokasi yang berbeda merujuk data yang dihimpun Badan Pusat Statistik (BPS). ${ }^{6}$ Banyaknya rumah susun yang terbangun, mendorong para pemilik dana, investor, dan/atau pengembang saling berinovasi dalam melakukan pembangunan rumah susun berfasilitas lengkap guna menarik minat pembeli yang sebanyak-banyaknya.

Salah satu inovasi atau terobosan terbaru dalam pembangunan rumah susun terlihat pada kawasan pusat perbelanjaan (mall) Thamrin City, yang terletak di Jl.

\footnotetext{
4 Urip Santoso II, Hak Atas Tanah, Hak Pengelolaan, Dan Hak Milik Atas Satuan Rumah Susun (Kencana 2017).[214].

5 Pasal 2 UU Undang-Undang Nomor 20 Tahun 2011 Tentang Rumah Susun (UU Rusun).

6 Aswin Saputra, 'Jumlah Rumah Susun Di DKI Jakarta' (2018) <https://lokadata.beritagar. $\mathrm{id} /$ chart/preview/jumlah-rumah-susun-di-dki-jakarta-1534228588> accessed 18 August 2019.
} 
K.H. Mas Mansyur, Kecamatan Tanah Abang, Jakarta Pusat, Provinsi DKI Jakarta. Mall Thamrin City memiliki 10 lantai bertingkat, di mana 7 tingkat diantaranya digunakan sebagai pusat perbelanjaan dan 4 lantainya dipergunakan untuk parkir7. Namun pada bagian teratas (lantai 10) Mall Thamrin City, ternyata tidak difungsikan sebagai pusat perbelanjaan, namun berdiri kawasan perumahan bernama Cosmo Park Townhouse, yang dikelola oleh pengembang PT. Jakarta Reality, sebuah anak perusahaan kerjasama antara PT. Agung Podomoro Group dan PT. Jakarta Propetindo. ${ }^{8}$ Jika ditinjau dari konstruksi bangunannya, kawasan Cosmo Park Townhouse dapat dikategorikan sebagai Perumahan sesuai definisi yang diatur dalam Pasal 1 angka 2 UU Perumahan, yaitu:

a. kumpulan rumah sebagai bagian dari permukiman: kawasan cosmo park adalah sebuah lingkungan hunian terdiri atas 78 unit rumah, dengan luas masing-masing rumah rata-rata $100 \mathrm{~m}^{2}$, sebagaimana disampaikan Sudarmi Yuliani, selaku Chief Customer Service The Jakarta Residence. ${ }^{9}$

b. baik perkotaan maupun perdesaan: kawasan cosmo park terletak di Provinsi DKI Jakarta, tepatnya pada kota Jakarta Pusat.

c. yang dilengkapi dengan prasarana, sarana, dan utilitas umum sebagai hasil upaya pemenuhan rumah yang layak huni: pada kawasan cosmo park terdapat beberapa sarana-prasarana yang dapat digunakan penghuni seperti: jalan, kolam renang, lapangan tenis, gymnastic/pusat fitness, minimarket, laundry dan sebagainya. ${ }^{10}$

Permasalahan hukum pada perumahan yang demikian adalah perihal status penguasan atas tanahnya, karena dalam bidang tanah tersebut di atas berdiri 2 bangunan yang terpisah, yaitu gedung Mall Thamrin City dan unit-unit rumah

\footnotetext{
7 Mahanik, 'Thamrin City Mall' (2012) <http://infopromodiskon.com/mall/profile/ thamrin-city-mall/> accessed 18 August 2019.

8 Triyono, 'Company Profile The Jakarta Propertindo' (Thamrin Residence, 2015) <https:// www.thamrinresidence.wordpess.com/company-profile/> accessed 18 August 2019.

9 Aini Putri Wulandari, 'Melihat Dari Dekat Rumah-Rumah Di Atas Gedung Thamrin City' (CNN Indonesia, 2019) <https://www.cnnindonesia.com/nasional/20190626162138-20-406652/ melihat-dari-dekat-rumah-rumah-di-atas-gedung-thamrin-city> accessed 17 August 2019.

${ }^{10}$ Prima Fauziah, 'Cosmo Park Thamrin City' (The Condotel, 2019) <http://thecondotel.com/ id/18/Cosmo_Park_Thamrin_City> accessed 17 August 2019.
} 
Cosmo Park Townhouse itu sendiri. Jika demikian, apakah status tanah yang dapat didirikan rumah, berupa: Hak Milik; HGB di atas Tanah Negara/Hak Pengelolaan; dan Hak Pakai atas Tanah Negara ${ }^{11}$ dapat mengakomodir penguasaan ganda tersebut? Atau apakah penguasaanya menggunakan ketentuan dalam UU Rusun meskipun konstruksi unit rumahnya berbentuk landed house bukan berupa satuan ruang (sarusun) yang digunakan secara terpisah dengan fungsi utama sebagai tempat hunian dan mempunyai sarana penghubung ke jalan umum. ${ }^{12}$ Sarusun memiliki kriteria khusus di antaranya: bersifat perorangan dan terpisah adalah ruang yang dibatasi oleh permukaan dinding, permukaan kolom, permukaan atas lantai (sebagai batas bawah) dan permukaan langit-langit (sebagai batas atas).$^{13}$ Perihal status penguasaan ini memang sulit untuk diuraikan apabila hanya merujuk definisi dalam undang-undang sebab berkaitan dengan perlindungan hak-hak masyarakat berupa kepastian hukum atas serangkaian wewenang, kewajiban, dan larangan bagi penghuni untuk berbuat atau tidak berbuat sesuatu terhadap unit rumah Cosmo Park Townhouse.

Agar pembangunan perumahan di atas gedung bertingkat semacam Cosmo Park Townhouse tidak menimbulkan antinomi/pertentangan ketentuan hukum antara UUPA, UUU Perumahan, dan UU Rusun, maka lebih lanjut akan penulis uraikan status penguasaan atas tanah dan sertipikat sebagai surat tanda bukti hak pada rumah susun saja, karena antara perumahan dan rumah susun secara umum memiliki pengaturan yang sama, namun perbedaanya pada rumah susun memiliki pola penguasaan atas tanah dan/atau bangunan yang berbeda karena: ${ }^{14}$ a. Rumah susun adalah nomenklatur atau padanan pada sistem hukum Indonesia untuk mengakomodir penguasaan bangunan gedung bertingkat secara individual maupun kolektif . Dalam sistem hukum pada negara-negara eropa,

${ }^{11}$ Pasal 43 Ayat (1) Undang-Undang Nomor 1 Tahun 2011 Tentang Perumahan Dan Kawasan Permukiman Juncto Pasal 16 Ayat (1) Undang-Undang Nomor 5 Tahun 1960 Tentang Peraturan Dasar Pokok-Pokok Agraria.

12 Pasal 1 Angka 3 Undang_Undang Nomor 20 Tahun 2011 Tentang Rumah Susun.

${ }_{13}$ Urip Santoso II (n 4). Op.Cit.[222].

14 Oloan Sitorus, Kondominium Dan Permasalahannya (Mitra Kebijakan Tanah Indonesia 1998). [16]. 
maka rumah susun merupakan terjemahan dari kata-kata condominium, flat atau apartment;

b. Rumah susun merupakan bangunan gedung bertingkat "yang distrukturkan secara fungsional dalam arah horizontal maupun vertikal". Kata "maupun" serta "dan" perlu dicermati oleh karena membawa konsekuensi pada ruang lingkup UU Rumah Susun.

c. Secara umum dikenal ada 3 (tiga) bentuk sistem pemilikan, yaitu : (i) sistem pemilikan perseorangan; (ii) sistem pemilikan bersama yang terikat; (ii) sistem pemilikan perseorangan yang sekaligus dilengkapi dengan sistem pemilikan bersama yang bebas.

\section{Status Hak Atas Tanah Yang Melekat Pada Rumah Susun}

Penentuan status hak atas tanah yang di atasnya didirikan bangunan rumah susun tergantung pada klasifikasi pelaku pembangunan. Sebagaimana ketentuan Pasal 1 angka 15 UU Rumah Susun yang dimaksud pelaku pembangunan adalah setiap orang dan/atau pemerintah yang melakukan pembangunan perumahan dan permukiman, dalam hal ini dapat berupa: ${ }^{15}$ Warga Negara Indonesia (WNI), Orang Asing yang berkedudukan di Indonesia, Badan hukum yang didirikan menurut hukum Indonesia dan berkedudukan di Indonesia, yaitu perseroan terbatas (PT) dan yayasan, Badan hukum asing yang mempunyai perwakilan di Indonesia, Badan Usaha Milik Negara (BUMN) berbentuk perusahaan umum dan perusahaan perseroan, Badan Usaha Milik Daerah (BUMD), Instansi yaitu lembaga negara, kementrian, lembaga Pemerintah non-kementrian, pemerintah provinsi, pemerintah kabupaten/kota. Sehubungan dengan klasifikasi pelaku pembangunan tersebut, maka Pasal 17 UU Rumah Susun menetapkan bahwa pembangunan untuk rumah susun dapat dilakukan di atas tanah : Hak Milik; Hak Guna Bangunan atas Tanah Negara; Hak Guna Bangunan atas Hak Pengelolaan; Hak Pakai atas Hak Pengelolaan; dan Hak Pakai atas Tanah Negara. Pengaturan 
tentang hak-hak atas tanah yang dapat digunakan sebagai pembangunan rumah susun tersebut pada hakikatnya tunduk pada pengaturan yang telah tertuang dalam UUPA, dengan uraian masing-masing sebagai berikut.

\section{Hak Milik}

Pasal 20 UUPA memberikan definisi tentang Hak Milik, yaitu hak turun temurun, terkuat, dan terpenuh yang dapat dipunyai orang atas tanah dengan mengingat ketentuan mengenai fungsi sosial hak atas tanah. Hak Milik ini dapat beralih dan dialihkan kepada pihak lain dengan prosedur yang berbeda sesuai dengan cara terjadinya, yaitu sebagaimana tercantum dalam Pasal 22 UUPA: menurut hukum adat, karena penetapan pemerintah, dan karena ketentuan undang-undang. Lalu, terkait hapusnya Hak Milik atas Tanah merujuk pada Pasal 27 UUPA, yang dapat dilakukan apabila: tanahnya jatuh kepada Negara; pencabutan hak karena Pengadaan Tanah untuk kepentingan umum, kepentigan bangsa dan negara, atau kepentingan bersama dari rakyat; penyerahan dengan sukarela oleh pemiliknya; diterlantarkan; memperoleh hak milik atas tanah yang dikuasai Orang Asing karena pewarisan tanpa wasiat atau percampuran harta karena perkawinan, atau karena suatu Hak Milik atas Tanah dikuasai oleh WNI yang kehilangan kewarganegaraan Indonesia. Ketentuan mengenai rumah atau perumahan yang dalam hal ini menurut penulis termasuk pula rumah susun, yang dibangun di atas tanah Hak Milik yaitu: ${ }^{16}$

a. Pihak yang menyelenggarakan pembangunan rumah susun adalah WNI, badan keagamaan dan badan sosial yang ditetapkan oleh Pemerintah, bank pemerintah, dengan memperhatikan ketentuan dalam Peraturan Pemerintah Nomor 38 Tahun 1963 Tentang Penunjukan Badan-Badan Hukum yang dapat mempunyai Hak Milik Atas Tanah; ${ }^{17}$

b. Tanah Hak Milik dapat berasal dari Tanah Negara, Tanah Hak Pengelolaan yang telah dilepaskan oleh pemegang haknya, atau bekas tanah adat yang telah dikonversi menjadi Hak Milik;

c. Masa penguasaan tanah yang di atasnya dibangun rumah susun di atas tanah Hak Milik tidak dibatasi oleh waktu tertentu atau berlaku selama pemilik

\footnotetext{
16 ibid. Op.Cit.[88].

17 Urip Santoso II (n 4). Op.Cit.[217].
} 
satuan rumah susun memenuhi syarat sebagai subjek Hak Milik;

d. Rumah susun yang dibangun di atas tanah Hak Milik maka terhadap satuan rumah susunnya dapat beralih atau dilaihkan kepada peorangan dan.atau badan hukum lain melalui pewarisan, jual-beli, tukar-menukar, hibah, inbreng, dan lelang tanpa persetujuan dari pihak lain terlebuh dahulu; ${ }^{18}$

e. Rumah susun yang dibangun di atas tanah Hak Milik maka terhadap satuan rumah susunnya dapat menjadi jaminan utang dengan dibebani Hak Tanggungan;

f. Rumah susun yang dibangun di atas tanah Hak Milik maka terhadap satuan rumah susunnya dapat ditempati oleh orang lain dengan cara sewa-menyewa atau bukan dengan sewa-menyewa.

\section{Hak Guna Bangunan, baik di atas Tanah Negara maupun di atas Hak Pengelolaan}

Hak Guna Bangunan (HGB) adalah hak untuk mendirikan dan mempunyai bangunan di atas tanah yang bukan miliknya sendiri, ${ }^{19}$ atas permintaan pemegang hak dan dengan mengingat keperluan serta keadaan bangunannya sebagaimana diatur dalam Pasal 35 UUPA. Pasal 21 Peraturan Pemerintah Nomor 40 Tahun 1996 Tentang Hak Guna Usaha, Hak Guna Bangunan, dan Hak Pakai Atas Tanah (selanjutnya disebut PP 40/1996) telah menentukan bahwa tanah yang dapat digunakan dengan HGB adalah Tanah Negara, Tanah Hak Pengelolaan dan Tanah Hak Milik. Meskipun HGB dapat digunakan pada ketiga hak atas tanah tersebut, namun UU Rumah Susun mengatur bahwa rumah susun hanya boleh dibangun di atas tanah HGB atas Tanah Negara atau Tanah Hak Pengelolaan saja. HGB atas tanah Negara diberikan dengan keputusan pemberian hak oleh Menteri atau pejabat yang ditunjuk. Sedangkan HGB atas tanah Hak Pengelolaan diberikan dengan keputusan pemberian hak oleh Menteri atau pejabat yang ditunjuk berdasarkan usul pemegang Hak Pengelolaan. Ketentuan mengenai rumah atau perumahan yang dalam hal ini menurut penulis termasuk pula rumah susun, yang dibangun di atas tanah HGB atas Tanah Negara dan HGB atas tanah Hak Pengelolaan adalah: ${ }^{20}$

${ }^{18}$ Urip Santoso III, Buku Ajar Hukum Pengadaan Dan Pendaftaran Hak Atas Tanah (Revka Petra Media 2018).[200].

19 Adrian Sutedi, Hukum Rumah Susun Dan Apartemen (Sinar Grafika 2010).[205].

${ }^{20}$ Urip Santoso I (n 15).Op.Cit.[94]. 
a. Pihak yang menyelenggarakan pembangunan rumah susun adalah WNI dan Badan Hukum yang didirikan menurut hukum Indonesia serta berkedudukan di Indonesia berbentuk perseroan terbatas (PT) atau yayasan apabila tanahnya berstatus HGB atas Tanah Negara. Apabila tanahnya berstatus HGB atas tanah Hak Pengelolaan, maka yang menyelenggarakan pembangunan rumah susun adalah BUMN yang berbentuk Perusahaan Umum Pembangunan Perumahan Nasional (Perum-Perumnas); ${ }^{21}$

b. Pihak yang dapat menguasai satuan rumah susun adalah WNI dan Badan Hukum yang didirikan menurut hukum Indonesia serta berkedudukan di Indonesia;

c. Masa penguasaan atas tanah yang di atasnya dibangun rumah susun di atas HGB adalah untuk pertama kali maksimal selama 30 tahun, yang untuk selanjutnya dapat diperpanjang paling lama 20 tahun, lalu setelah habis dapat diperbarui haknya selama-lamanya dalam 30 tahun. Perpanjangan masa penguasaan dan pembaharuan HGB atas Hak Pengelolaan dapat dilakukan setelah mendapat persetujuan secara tertulis dari pemegang Hak Pengelolaan;

d. Rumah susun yang dibangun di atas tanah HGB maka terhadap satuan rumah susunnya dapat beralih atau dilaihkan kepada perorangan dan/atau badan hukum lain melalui pewarisan, jual-beli, tukar-menukar, hibah, dan inbreng, serta dapat pula dijadikan jaminan utang dengan dibebani Hak Tanggungan. Setiap tindakan hukum pada satuan rumah susun yang alas pendiriannya menggunakan HGB atas tanah Hak Pengelolaan hanya dapat dilakukan setelah mendapat persetujuan dari pemegang Hak Pengelolaan, sedangkan pada rumah susun yang alas pendiriannya menggunakan HGB atas Tanah Negara, maka tidak diperlukan persetujuan dari pihak lain; ${ }^{22}$

e. Rumah susun yang dibangun di atas tanah HGB maka terhadap satuan rumah susunnya dapat ditempati oleh orang lain dengan cara sewa-menyewa atau bukan dengan sewa-menyewa.

\section{Hak Pakai, baik di atas Tanah Negara maupun di atas Hak Pengelolaan}

Hak Pakai adalah hak untuk menggunakan dan/atau memungut hasil dari tanah yang dikuasai langsung oleh Negara atau tanah milik orang lain. ${ }^{23}$ Hak Pakai atas tanah pada pokoknya memberi wewenang dan kewajiban yang ditentukan, apabila di atas tanah negara maka akan tertuang dalam Surat Keputusan Pemberian Hak Pakai oleh Kepala Badan Pertanahan Nasional Republik Indonesia/Kepala

Kantor Wilayah Badan Pertanahan Nasional Provinsi/ Kepala Kantor Pertanahan

\footnotetext{
${ }^{21}$ Urip Santoso II (n 4). Loc.cit.

${ }^{22}$ Urip Santoso III (n 18). Loc.cit.

${ }^{23}$ Urip Santoso IV, Hukum Agraria : Kajian Komperehensif, Cetakan Ke-6 (Kencana 2013).[119].
} 
Kabupaten-Kota. ${ }^{24}$ Sedangkandalam halHak Pakai diatas tanahyang telah dikuasai orang lain, wewenang dan kewajiban tersebut tertuang dalam perjanjian yang bukan sewa menyewa atau perjanjian pengolahan. Asal tanah Hak Pakai menurut Pasal 41 ayat (1) UUPA adalah tanah Negara dan tanah Hak Milik, namun PP 40/1996 memperluas memperluas asal tanah Hak Pakai yang meliputi pula tanah Hak Pengelolaan. Meski demikian, ketentuan UU Rumah Susun mengatur bahwa Hak Pakai yang dapat dijadikan dasar pembangunan rumah susun hanya Hak Pakai atas Tanah Negara dan Hak Pakai atas tanah Hak Pengelolaan. Ketentuan mengenai rumah atau perumahan yang dalam hal ini menurut penulis termasuk pula rumah susun, yang dibangun di atas tanah Hak Pakai atas Tanah Negara atau Hak Pakai atas tanah Hak Pengelolaan, sebagai berikut: ${ }^{25}$

a. Pihak yang menyelenggarakan pembangunan apabila Hak Pakai di atas Tanah Negara yaitu WNI, Orang Asing yang berkedudukan di Indonesia, BUMN, BUMD, Kementrian, Lembaga Pemerintah Non-Kementrian, Badan Otorita, Badan Keagamaan, Badan Sosial, dan Badan Usaha Swasta yang berbentuk Perseroan Terbatas (PT). Sedangkan apabila Hak Pakainya berada di atas tanah Hak Pengelolaan maka yang berhak membangun hanya BUMN yang berbentuk Perusahaan Umum Pembangunan Perumahan Nasional (Perum-Perumnas). ${ }^{26}$

b. Rumah susun yang dibangun dapat berjenis rumah susun umum, rumah susun khusus, rumah susun negara, dan rumah susun komersial;

c. Pihak yang dapat memiliki atau menguasai satuan rumah susun adalah WNI, Badan Hukum yang didirikan menurut hukum Indonesia dan berkedudukan di Indonesia, Orang Asing yang berkedudukan di Indonesia, serta badan hukum asing yang mempunyai perwakilan di Indonesia;

d. Masa penguasaan tanah atas Hak Pakai berbeda bergantung pada jenis Rumah Susun yang dibangun di atasnya. Pada jenis rumah susun umum dan rumah susun komersial, Hak Pakai untuk pertama kali berjangka waktu 25 tahun, kemudian dapat diperpanjang maksimal selama 20 tahun, lalu dapat diperbarui haknya untuk jangka waktu paling lama 25 tahun. Sedangkan untuk jenis rumah susun khusus dan rumah susun negara masa penguasaan atas tanahnya tidak dibatasi dengan jangka waktu tertentu, karena Hak Pakainya berlaku sepanjang tanahnya digunakan digunakan untuk kepentigan yang bersangkutan.

e. Rumah susun yang dibangun di atas tanah Hak Pakai, maka terhadap satuan rumah susunnya ada yang dapat atau tidak dapat beralih/dialihkan kepada pihak lain oleh pemegang haknya, begitu pula ada yang dapat dan tidak

\footnotetext{
${ }^{24}$ Urip Santoso I (n 15). Op.Cit.[426].

25 ibid.[101].

${ }^{26}$ Urip Santoso II (n 4). Loc.cit.
} 
dapat dijadikan jaminan utang dengan dibebani Hak Tanggungan. Dapat atau tidaknya tindakan-tindakan hukum tersebut bergantung pada status hak atas tanah yang melekat pada Hak Pakainya. Apabila rumah susunnya didirikan di atas tanah Hak Pakai yang bersifat privat, maka segala tindakan hukum dapat dilakukan dengan persetujuan dari Kantor Pertanahan Kabupaten/Kota, kemudian jika didirikan di atas tanah Hak Pakai atas tanah Hak Pengelolaan, maka persetujuannya adalah oleh pemegang Hak Pengelolaanya. Sedangkan Hak Milik atas Satuan Rumah Susun yang tidak dapat dipindahtangankan atau dijadikan hak tanggungan adalah apabila rumah susunnya didirikan di atas tanah Hak Pakai atas Tanah Negara. ${ }^{27}$

f. Rumah susun yang dibangun di atas tanah Hak Pakai, maka terhadap satuan rumah susunnya dapat ditempati oleh pihak lain dengan cara sewa-menyewa atau bukan dengan sewa-menyewa.

\section{Hak Milik Atas Satuan Rumah Susun}

Sistem bangunan/gedung bertingkat yang ruang-ruangnya dapat dipakai secara individual telah lama dipraktekkan di Indonesia, dimana pemegang hak atas tanahnya sekaligus sebagai pihak yang berhak memiliki gedung. Pada permulaanya, hubungan hukum yang mendasari penghunian gedung bertingkat adalah sewa-menyewa antara pemilik tanah -yang sekaligus sebagai pemilik bangunan- dengan para pemakai dari ruang-ruang dalam bangunan/gedung bertingkat tersebut. ${ }^{28}$ Pada perkembangannya, disahkannya UU Rumah Susun menjadikan kepemilikan atas bangunan/gedung bertingkat ini kemudian dapat mengakomodir hak kebendaan bagi individu-masyarakat secara luas dengan dilandasi oleh konsep bangunan rumah susun yang berdiri di atas hak atas tanah tertentu. Hak atas tanah tersebut dimiliki atau dikuasai secara bersama-sama oleh seluruh pemilik satuan rumah susun atau pemilik satuan ruang dalam suatu gedung bertingkat. Pemilikan atau penguasaan hak atas tanah secara bersamasama telah diatur pula dasarnya oleh Pasal 4 ayat (1) UUPA, yang menyatakan:

"Atas dasar hak menguasai dari Negara sebagai yang dimaksud dalam pasal 2, ditentukan adanya macam-macam hak atas permukaan bumi yang disebut tanah, yang dapat diberikan kepada dan dipunyai oleh orangorang, baik sendiri maupun bersama-sama dengan orang-orang lain serta

\footnotetext{
${ }^{27}$ Urip Santoso III (n 18).. Loc.cit.

${ }^{28}$ Adrian Sutedi (n 19). Op.Cit.[198].
} 
badan-badan hukum".

Redaksional kalimat "bersama-sama dengan orang-orang lain serta badanbadan hukum" di atas menunjukkan bahwa hak atas tanah dapat dimiliki atau dikuasai oleh lebih dari satu orang secara bersama-sama. ${ }^{29}$ Menurut Adrian Sutedi, ketentuan Pasal 4 ayat (1) UUPA tersebut berpangkal dari konsep pemilikan bersama atas suatu objek yang pada intinya dikenal dengan adanya 2 (dua) macam kepemilikan, yaitu: ${ }^{30}$

a. Pemilikan Bersama Terikat, yaitu adanya ikatan hukum yang terlebih dahulu ada di antara para pemilik objek bersama, misalnya pemilikan bersama yang terdapat pada harta perkawinan pasangan suami-istri. Para pemilik bersama tidak dapat secara bebas melakukan pemindahan/pengalihan hak atas objek tertentu kepada pihak lain tanpa adanya persetujuan dari pihak lainnya atau selama suami-istri masih dalam ikatan perkawinan, tidak memungkinkan untuk melakukan pembagian ataupun harta perkawinan kecuali telah ada perjanjian kawin. Hal ini berlaku pula apabila suami-istri tadi meninggal dunia dengan meninggalkan harta sebidang tanah misalnya, maka tanah pewaris tersebut pada hakikatnya dimiliki secara bersama-sama oleh seluruh ahli warisnya.

b. Pemilikan Bersama Bebas, adalah dimaksudkan bahwa setiap para pemilik bersama tidak terdapat ikatan hukum terlebih dahulu selain dari hak bersama atas suatu objek. Sehingga dalam hal ini adanya kehendak kolektif untuk menjadi pemilik atas suatu objek yang dapat digunakan secara bersama-sama. Bentuk kepemilikan bebas ini kemudian berkembang menjadi UU Rumah Susun yang merumuskan jenis pemilikan perorangan dan pemilikan bersama dalam suatu kesatuan jenis pemilikan baru yang disebut Hak Milik Atas Satuan Rumah Susun. Hak kepemilikan perseorangan dalam Satuan Rumah Susun adalah kepemilikan untuk ruangnya, ${ }^{31}$ sehingga dapat mengakomodir kebutuhan masyarakat akan

${ }^{29}$ Urip Santoso I (n 15). Op.Cit.[402].

30 Adrian Sutedi (n 19). Loc.cit.

31 J. Andy Hartanto, 'Kepemilikan Hak Milik Atas Satuan Rumah Susun' (2013) 02 Jurnal Rechtens Universitas Islam Jember.[9]. 
penguasaan atas tanah secara kolektif yang di atasnya dibangun sebuah Rumah Susun atau Gedung Bertingkat. Ruang lingkup kepemilikan satuan rumah susun ditetapkan dalam Pasal 46 ayat (1) UU Rumah Susun, yaitu meliputi: ${ }^{32}$

a. Bagian Bersama

Dalam Pasal 1 angka 5 UU Rumah Susun disebutkan definisinya, yaitu bagian rumah susun yang dimiliki secara tidak terpisah untuk pemakaian bersama dalam kesatuan fungsi dengan satuan-satuan rumah susun. Bagian bersama ini sebagaimana ketentuan Pasal 20 Peraturan Pemerintah Nomor 4 Tahun 1988 Tentang Rumah Susun (selanjutnya disebut PP Rumah Susun) dapat berupa ruang untuk umum, ruang tangga, lift, dan selasar, serta termasuk juga pondasi, kolom, balok, dinding lantai, atap, talang air, saluran, pipa, jaringan listrik, gas dan telekomunikasi, dinding-dinding struktur utama, ruang masuk, koridor, pintu-pintu, tangga darurat, jalan masuk serta jalan ke luar dari rumah susun.

b. Benda Bersama

Sebagaimana tercantum dalam Pasal 1 angka 6 UU Rumah Susun adalah benda yang bukan merupakan bagian rumah susun melainkan bagian yang dimiliki bersama secara tidak terpisah untuk pemakaian bersama. Dalam Pasal 21 PP Rumah Susun, benda bersama harus memiliki dimensi, lokasi, kualitas, kapasitas, sehingga dalam hal ini contohnya antara lain ruang pertemuan, tanaman, bangunan pertamanan, bangunan sarana sosial, tempat ibadah, tempat bermain, tempat parkir, instalasi tenaga listrik, lampulampu, gas, air panas dan dingin, instalasi air conditioner, pompa air, motor tenaga listrik (generator), kipas angin, kompresor, saluran-saluran ducting/penghantar air conditioner.

c. Tanah Bersama

Jika merujuk definisinya dalam Pasal 1 angka 4 UU Rumah Susun adalah sebidang tanah hak atau tanah sewa untuk bangunan yang digunakan atas

\footnotetext{
${ }^{32}$ Urip Santoso II (n 4). Op.Cit.[222].
} 
dasar hak bersama secara tidak terpisah yang di atasnya berdiri rumah susun dan ditetapkan batasnya dalam persyaratan izin mendirikan bangunan.

Besarnya hak atas Bagian Bersama, Benda Bersama, dan Tanah Bersama di atas masing-masing didasarkan atas luas atau nilai sarusun menggunakan Nilai Perbandingan Proporsional (NPP) sebagaimana ketentuan Pasal 1 angka 16 UU Rumah Susun, yaitu:

"angka yang menunjukkan perbandingan antara sarusun terhadap hak atas bagian bersama, benda bersama, dan tanah bersama yang dihitung berdasarkan nilai sarusun yang bersangkutan terhadap jumlah nilai rumah susun secara keseluruhan pada waktu pelaku pembangunan pertama kali memperhitungkan biaya pembangunannya secara keseluruhan untuk menentukan harga jualnya".

NPP ini juga menentukan besarnya imbangan kewajiban masing-masing pemilik sarusun dalam membiayai pengelolaan 3 (tiga) komponen hak bersama yang melekat pada rumah susun. ${ }^{33}$ Biaya pengelolaan didistribusikan untuk kegiatan operasional kebersihan, pemeliharaan benda bersama, dan perawatan bagian bersama yang lazim disebut sebagai Iuran Pengelolaan Lingkungan (IPL). IPL pada beberapa rumah susun disebut dengan Service Charge atau Maintenance Fee merupakan kewajiban untuk membayar biaya sebagai beban bersama semua pemilik sarusun, namun nominal pembayarannya disesuaikan dengan luas unit sarusun yang dimiliki.

\section{Analisis Hak Penguasaan atas Tanah dan Bangunan Berdasarkan Studi Kasus Cosmo Park Townhouse Jakarta}

Penguasaan dalam penelitian ini adalah dalam arti fisik, mengutip Satjipto Rahardjo, ${ }^{34}$ yaitu adanya hubungan yang nyata sebuah subjek dengan objek yang ada dalam penguasaanya. Penguasaan fisik selanjutnya ditentukan oleh ada atau tidaknya pengakuan hukum untuk mendapat perlindungan. Karena dibutuhkan sebuah pengakuan hukum tersebutlah, penguasaan tidak cukup dimaknai dalam

\footnotetext{
${ }^{33}$ Adrian Sutedi (n 19). Op.Cit.[145].

34 Satjipto Rahardjo, Ilmu Hukum (Citra Aditya Bakti 2000).[62].
} 
arti fisik saja, namun juga dalam arti yuridis, yaitu penguasaan yang dilandasi hak yang dilindungi oleh hukum dan pada umumnya berisi serangkaian wewenang, kewajiban dan/atau larangan bagi subjek sebagai pemegang hak untuk berbuat sesuatu mengenai objek yang dihaki. ${ }^{35}$ Yang perlu diperhatikan dalam mengurai status penguasaan dan/atau kepemilikan unit rumah Cosmo Park Townhouse ini adalah hubungan hukum antara subjek, yaitu pemilik/penghuni, dengan objek yang berupa: bangunan gedung 9 (sembilan) tingkat Mall Thamrin City; bangunan hunian Cosmo Park Townhouse pada lantai 10; dan bidang tanah di Jl. K.H. Mas Mansyur, Kecamatan Tanah Abang, Jakarta Pusat yang menjadi alas pendirian bangunan. Sehubungan dengaan hal tersebut, ada dua macam asas dalam hubungan hukum antara orang dengan tanah, yaitu: ${ }^{36}$ Asas Accesie atau Asas Perlekatan dan Asas Horizontale Scheiding atau Asas Pemisahan Horisontal.

Asas yang digunakan dalam hukum tanah yang berlaku saat ini adalah Asas Pemisahan Horisontal, yang pada hakekatnya bersumber pada hukum adat. Pandangan demikian sesuai dengan realitas di pedesaan dimana bangunanbangunan dibuat dari kayu dan bambu sehingga menurut kenyataannya memang tidak merupakan satu kesatuan dengan tanahnya. Dengan adanya asas pemisahan horisontal ini, maka tanah terpisah dari segala sesuatu yang berada di atasnya dan melekat dengan tanah tersebut, sehingga pemilik hak atas tanah dan pemilik bangunan yang berada di atasnya dapat berbeda. Asas pemisahan horizontal membawa akibat hukum diantaranya: ${ }^{37}$

a. Belum tentu pemilik sebidang tanah adalah pemilik dari segala tanaman atau bangunan yang berdiri di atas tanah tersebut juga, pun sebaliknya, tidak pasti bahwa pemilik segala tanaman atau bangunan yang berdiri di atas sebidang tanah adalah juga pemilik dari tanah yang bersangkutan beserta segala isinya yang terkandung di dalamnya.

b. Karena itu dalam asas pemisahan ini sangat dimungkinkan seseorang atau

${ }^{35}$ Urip Santoso IV (n 23). Op.Cit.[75].

36 ibid.[12].

37 Ridwan Halim, Sari Hukum Hak Milik, Kondominium Dan Rumah Susun (Puncak Karma Penerbit Buku Berguna 1990).[179]. 
suatu pihak "menumpang" di atas tanah orang lain, baik penumpangan itu berupa penumpangan pendirian rumah/ bangunan ataupun berupa penumpangan penananman tanaman atau tumbuhan tertentu;

c. Jadi dengan perkataan lain, pemilik dari sebidang atau sepersil tanah tertentu belum tentu adalah juga pemilik dari segala sesuatu yang ada di atas tanah tersebut Berdasarkan asas pemisahan horisontal, dimungkinkan dalam satu bidang tanah yang sama terdapat beberapa hak kepemilikan atas tanah secara bersamaan. Meski demikian, menurut Adrian Sutedi dalam suasana sekarang ini dimana bangunanbangunan dibuat dari pondamen batu yang sulit dibongkar dan merupakan satu kesatuan dengan tanahnya, penerapan Asas Pemisahan Horisontal tidak harus berlaku secara mutlak. Artinya dengan memperhatikan faktor-faktor konkrit dan realita yang demikian, maka untuk menentukan keberlakuan hukum terhadap tanah dan bangunan secara kesatuan atau dipisahkan, akan selalu ada kemungkinan untuk mengadakan penyimpangan dengan tetap mengingat tujuan dan pengunaan ketentuan peraturan yang bersangkutan agar supaya penyelesaiannya dapat memenuhi rasa keadilan. ${ }^{38}$

Kaitanya dengan penguasaan atas satuan unit rumah pada Cosmo Park Townhouse, adalah bahwa pemilikan hak atas tanah pada sarusun tidak sepenuhnya menganut asas pemisahan horisontal karena kepemilikan atas tanah pada satuan rumah susun merupakan kepemilikan bersama dari seluruh pemegang hak milik atas satuan rumah susun, bukan merupakan kepemilikan perorangan sebagaimana yang dianut dalam asas pemisahan horisontal dalam UUPA. ${ }^{39}$

Lalu, meskipun bangunan fisik unitnya bukan berupa sarusun tetapi berbentuk landed house, hal yang demikian tidak dapat dikategorikan sebagai lingkungan hunian berbentuk perumahan dan/atau permukiman seperti diatur dalam UU Perumahan. Hal ini dikarenakan hak atas tanah yang diperoleh penghuni/ pemilik unit Cosmo Park Townhouse berbeda dengan hak atas tanah yang diperoleh penghuni/pemilik rumah dalam komplek permikiman.

\footnotetext{
${ }^{38}$ Adrian Sutedi (n 19). Op.Cit.[164].

39 J. Andy Hartanto (n 31). Op.Cit.[9].
} 
Apabila seseorang membeli/menyewa rumah pada komplek permukiman, status kepemilikan/penguasaannya akan terwujud dalam Sertipikat Hak Atas Tanah, yaitu merujuk ketentuan Pasal 16 ayat (1) UUPA dapat berupa: Hak Milik, Hak Guna Bangunan, Hak Guna Usaha, Hak Pakai, Hak Sewa Untuk Bangunan, Hak Membuka Tanah, Hak Memungut Hasil Hutan. Macam-macam hak atas tanah tersebut memberikan wewenang kepada pemilik/penghuni rumah untuk mempergunakan dan/atau mengambil manfaat dari tanah di bawahnya. Frasa "menggunakan" mengandung makna bahwa hak atas tanah diperlukan untuk mendirikan bangunan, sedangkan frasa "mengambil manfaat" mengandung pengertian bahwa hak atas tanah untuk keperluan pertanian, peternakan, dan perkebunan. ${ }^{40}$ Dengan demikian, seorang pemilik/penghuni rumah pada permukiman yang status penguasaanya terwujud dalam Hak Atas Tanah maka akan dapat terakomodir kebutuhan atas pemilikan bangunan di atas tanah, tanah di halaman rumahnya, tanah yang berada di bawah rumahnya, serta apa yang ada di atas bangunan rumah tersebut. ${ }^{41}$

Sedangkan pada Cosmo Park Townhouse, pemilik/penghuninya hanya berhak atas unit rumah yang dibeli/disewanya, dan tidak berhak menggunakan seluruh bangunan gedung bertingkat yang terdiri atas 10 (sepuluh) lantai, kemudian tidak berhak pula untuk mengambil manfaat bidang tanah di dalam lingkungan Thamrin City secara keseluruhan. Apabila pemilik/penghuni unit Cosmo Park Townhouse dianggap memiliki Hak Atas Tanah yang sama dengan pemilik/penghuni rumah pada kawasan permukiman, maka akan terjadi timpang-tindih hak dengan para pedagang yang berada di lantai 1-7, juga dengan para pengelola kantor di lantai 8 yang telah menguasai/menyewa/memiliki satuan ruang pada Thamrin City Mall. Isu hukum lain yang perlu juga diurai dalam sub-bab ini untuk mencegah timpangtindih hak atau ketidakpastian hukum yang merugikan di kemudian hari, yaitu apakah Cosmo Park Townhouse yang bangunan fisik unitnya bukan berupa satuan ruang namun berbentuk landed house dapat tunduk pada ketentuan UU Rumah

\footnotetext{
${ }^{40}$ Urip Santoso IV (n 23). Op.Cit.[84].

${ }^{41}$ Adrian Sutedi (n 19). Op.Cit.[146].
} 
Susun? Terhadap isu hal ini penulis akan meninjau terlebih dahulu terkait definisi Rumah Susun sebagaimana Pasal 1 angka 1 UU Rumah Susun, adalah:

“bangunan gedung bertingkat yang dibangun dalam suatu lingkungan yang terbagi dalam bagian-bagian yang distrukturkan secara fungsional, baik dalam arah horizontal maupun vertikal dan merupakan satuan-satuan yang masing-masing dapat dimiliki dan digunakan secara terpisah, terutama untuk tempat hunian yang dilengkapi dengan bagian bersama, benda bersama, dan tanah bersama".

Definisi tersebut tidak berbeda dengan definisi yang sebelumnya diatur pada UU Rumah Susun yang lama, yaitu Undang-Undang Nomor 16 Tahun 1985 (selanjutnya disebut UU Rusun Lama). Perbedaannya, dalam UU Rumah Susun tidak dicantumkan penjalasan atas muatan definisi Rumah Susun, sedangkan dalam UU Rusun Lama penjelasannya adalah sebagai berikut:

"rumah susun yang dimaksudkan dalam Undang-undang ini, adalah istilah yang memberikan pengertian hukum bagi bangunan gedung bertingkat yang senantiasa mengandung sistem pemilikan perseorangan dan hak bersama, yang penggunaannya untuk hunian atau bukan hunian, secara mandiri ataupun secara terpadu sebagai satu kesatuan sistem pembangunan".

Meskipun dengan berlakunya UU Rumah Susun maka juga menetapkan seluruh ketentuan dalam UU Rusun Lama tidak berlaku, namun penjelasan atas definisi RumahSusun pada UU Rusun Lama masih relevan dan dapat diaplikasikan untuk mengakomodir status penguasaan atas perumahan yang dibagun di atas gedung bertingkat seperti Cosmo Park Townhouse, karena meskipun konstruksinya berupa landed house dan bukan berbentuk satuan ruang, namun masih dapat termasuk dalam kategori gedung bertingkat.

Pasal 79 PP Rumah Susun sebenarnya juga telah mencontohkan bahwa "rumah toko, rumah sarana industri, rumah-rumah peristirahatan, rumah kota (townhouse) yang dibangun di atas tanah bersama" adalah bangunan bertingkat yang tidak termasuk dalam pengertian rumah susun namun masih tunduk pada ketentuan dalam Peraturan Pemerintah ini. Kiranya, dari kedua pendapat tersebut jika dihubungkan dengan ketentuan Pasal 1 angka 1 UU Rumah Susun jo. Pasal 79 PP Rumah Susun, maka dapat penulis simpulkan bahwa penguasaan atas unit Cosmo Park Townhouse dapat tunduk pada ketentuan UU Rumah Susun, sehingga antara para pedagang yang berada di 
lantai 1-7, para pengelola kantor di lantai 8, dan pemilik/penghuni unit Cosmo Park Townhouse dapat diakomodir hak bersamanya yang berupa Bagian Bersama, Benda Bersama, dan Tanah Bersama berdasarkan Nilai Perbandingan Proporsional.

\section{Sertipikat Hak Milik Atas Satuan Rumah Susun (SHM Sarusun) Sebagai Surat Tanda Bukti Hak}

Pasal 1 angka 1 UU Rumah Susun menyatakan SHM Sarusun merupakan tanda bukti kepemilikan sarusun di atas tanah Hak Milik, Hak Guna Bangunan/ Hak Pakai di atas Tanah Negara, dan Hak Guna Bangunan/Hak Pakai di atas Tanah Hak Pengelolaan. SHM Sarusun ini merupakan sebuah inovasi dalam rezim hukum agraria, karena selain sebagai alat bukti kepemilikan satrusun secara individual, juga merupakan alat bukti kepemilikan secara bersama yang mencantumkan dengan lengkap hak atas bagian bersama, benda bersama dan tanah bersama, ${ }^{42}$ yang dalam hal ini sebenarnya tidak menunjuk kepada bagian atau lokasi tertentu, tetapi dalam bentuk proporsi atau prosentase kepemilikan. ${ }^{43}$ Karakterisktik khusus yang lain adalah SHM Sarusun tidak terikat pada macam hak atas tanah.

Artinya, bagi satuan rumah susun yang berdiri di atas tanah Hak Milik, Hak Guna Bangunan, ataupun Hak Pakai, semuanya tetap menggunakan Sertipikat Hak Milik Atas Satuan Rumah Susun (SHM Sarusun) sebagai surat tanda bukti kepemilikannya. Berbeda halnya pada sertipikat hak atas tanah pada umumnya yang mana nama sertipikatnya sesuai dengan status hak atas tanahnya. Sebagai contoh Sertipikat Hak Milik adalah tanda bukti hak atas tanah Hak Milik, lalu Sertipikat Hak Guna Usaha apabila status tanahnya adalah HGU, dan Sertpikat Hak Guna Bangunan diperuntukkan bagi tanah yang menggunakan HGB. ${ }^{4}$ Perbedaan selanjutnya menurut Adrian Sutedi terletak pada: ${ }^{45}$

a. Pada rumah susun, pemisahan dilakukan sebelum satuan rumah susun dijual

${ }^{42}$ Urip Santoso I (n 15). Op.Cit.[436].

${ }^{43}$ Adrian Sutedi (n 19).Op.Cit.[142].

${ }^{44}$ Urip Santoso I (n 15).Loc.cit.

45 Felicia Melissa Yuanita, Keabsahan Condomonium Hotel Yang Dibangun Di Atas Tanah Hak Guna Bangunan Atas Tanah Hak Milik Dari Perspektif Undang-Undang Nomor 20 Tahun 2011 Tentang Rumah Susun, Tesis (Fakultas Hukum Universitas Airlangga 2014).[84]. 
yang selanjutnya terbit SHM Sarusun atas nama penyelenggara pembangunan. Adanya SHM Sarusun merupakan syarat dapat menjual satuan rumah susun.

b. Pada perumahan biasa, pemecahan dilakukan setelah rumah yang bersangkutan dijual. Atas dasar jual beli tersebut, terbit sertipikat atas nama pemilik yang baru. Barulah setelah SHM Sarusun terbit, pelaku pembangunan berhak untuk menjual unit rumah susun yang telah dibangun. Prinsip yang ada di ketentuan ini adalah penjualan rumah susun dapat dilakukan setelah terbitnya Izin Kelayakan. Artinya bahwa satuan rumah susun tidak dapat dijual apabila belum ada penilian layak/ tidak layak rumah susun untuk dihuni. Bagi para calon pembeli sarusun, untuk mengetahui apakah sebuah rumah susun yang ditawarkan pengembang telah selesai terbangun atau belum, maka harus diketahui unsur-unsur penerbitan SHM Sarusun dalam sub pembahasan berikut.

\section{Izin Mendirikan Bangunan}

Di dalam UU Rumah Susun, keberadaan IMB merupakan ketentuan administratif yang harus dipenuhi sebelum pembangunan rumah susun yang diatur pada Pasal 28. Definisi IMB sebagaimana Pasal 1 angka 2 Peraturan Menteri Pekerjaan Umum Dan Perumahan Rakyat Republik Indonesia Nomor 19/ Prt/M/2018 Tentang Penyelenggaraan Izin Mendirikan Bangunan Gedung dan Sertifikat Laik Fungsi Bangunan Gedung Melalui Pelayanan Perizinan Berusaha Terintegrasi Secara Elektronik (selanjutnya disebut Permen PUPR 19/2018), adalah:

"perizinan yang diberikan oleh pemerintah daerah kecuali untuk bangunan gedung fungsi khusus oleh Pemerintah kepada pemilik bangunan gedung untuk membangun baru, mengubah, memperluas, mengurangi, dan/atau merawat bangunan gedung sesuai dengan persyaratan administratif dan teknis yang berlaku".

Sebagaimana tercantum dalam Penjelasan Pasal 24 huruf b UU Rumah Susun, IMB sebagai syarat adminstratif pembangunan adalah instrumen hukum untuk menilai struktur bangunan, keamanan dan keselamatan bangunan, kesehatan lingkungan, kenyamanan, dan lain-lain yang berhubungan dengan rancang bangun, termasuk 
kelengkapan prasarana dan fasilitas lingkungan. Sehingga dalam Pasal 4 ayat (2) Permen PUPR 19/2018 kriteria penerbitan IMB adalah:

a. tanda bukti status kepemilikan hak atas tanah atau tanda bukti perjanjian pemanfaatan tanah;

b. data pemilik Bangunan Gedung; dan

c. rencana teknis Bangunan Gedung. paling sedikit memuat: rencana arsitektur, rencana struktur, dan rencana utilitas.

Ketentuan tersebut telah sesuai dengan peraturan perundangan-undangan di atasnya yaitu sebagaimana diatur melalui Pasal 15 ayat (1) Peraturan Pemerintah Nomor 36 Tahun 2005 Tentang Peraturan Pelaksanaan Undang-Undang Nomor 28 Tahun 2002 Tentang Bangunan Gedung (selanjutnya disebut PP 36/2005), yaitu:

"Permohanan Izin Mendirikan Bangunan yang akan diajukan kepada Pemerintah Daerah harus dilengkapi dengan:

a. Tanda bukti status kepemilikan hak atas tanah atau tanda bukti perjanjian pemanfaatan tanah;

b. Data pemilik bangunan gedung;

c. Rencana teknis bangunan gedung; dan

d. Hasil analisis mengenai dampak lingkungan bagi bangunan gedung yang akan menimbulkan dampak penting terhadap lingkungan".

\section{Pertelaan Rumah Susun}

Sebagaimana tertuang dalam Pasal 30 huruf c UU Rumah Susun, Pertelaan adalah sebuah gambar atau denah yang dapat menunjukkan batas masing-masing satuan rumah susun, bagian bersama, benda bersama, dan tanah bersama, beserta pula nilai perbandingan proporsionalnya (NPP) yang diuraikan. Menurut Pasal 30 UU Rumah Susun tersebut pula perusahaan swasta selaku pelaku pembangunan wajib meminta pengesahan atas pertelaannya kepada Pemerintah Daerah setelah diterbitkannya IMB. Dalam hal pembangunan Cosmo Park Townhouse, maka PT. Jakarta Reality selaku pengembang mengajukan permohonan pengesahan pertelaan kepada Gubernur DKI Jakarta sesuai ketentuan Pasal 29 ayat (3) UU Rumah Susun. Pengesahan pertelaan yang menunjukkan NPP hasil perhitungan perusahaan swasta oleh kepala daerah menjadi penting sebagai bentuk legitimasi 
terhadap gambaran hak dan kewajiban masing-masing pemilik terhadap penghunian rumah susun ke depannya.

Selain itu, Pertelaan juga menjadi salah satu syarat untuk pengesahan dokumen lain untuk dapat diterbitkan SHM Sarusun, yaitu sertifikat laik fungsi dan akta pemisahan rumah susun. Tanpa adanya pertelaan, maka SHM Sarusun tidak dapat diterbitkan oleh Kantor Pertanahan Kabupaten/Kota, karena pertelaan merupakan satu kesatuan dari buku tanah hak milik sarusun dan gambar denah sarusun yang kesemuanya adalah unsur-unsur kumulatif dariSHMSarusun sesuai yang diatur pada Pasal 47 ayat (3) UU Rumah Susun. Secara singkat proses pertelaan dimulai dengan pengajuan permohonan melalui Badan Pertanahan Nasional (BPN) kepada Gubernur lalu dilanjutkan dengan penelitian yang dilakukan oleh beberapa instansi terkait yang berkordinasi dengan Kepala BPN. Berdasarkan laporan penelitian instansi terkait tersebut nantinya akan dikeluarkan Keputusan Pengesahan Pertelaan oleh Gubernur dalam wilayah DKI Jakarta. ${ }^{46}$ Permohonan pengesahan pertelaan Cosmo Park Townhouse yang diajukan PT. Jakarta Reality harus memenuhi syarat administratif berupa: Salinan sertipikat hak atas tanah bersama yang dilegalisir oleh Kantor Pertanahan Kota Adminstratif Jakarta pusat; Salinan Izin Mendirikan Bangunan yang dilegalisir oleh biro hukum pemerintah provinsi DKI Jakarta; dan uraian pertelaan keseluruhan rumah susunnya.

\section{Sertifikat Laik Fungsi}

Definisi Sertifikat Laik Fungsi (SLF) dalam Pasal 1 angka 3 Permen PUPR 19/2018, adalah:

"sertifikat yang diterbitkan oleh pemerintah daerah kecuali untuk bangunan gedung fungsi khusus oleh Pemerintah untuk menyatakan kelaikan fungsi suatu bangunan gedung baik secara administratif maupun teknis, sebelum pemanfaatannya".

SLF merupakan dokumen persyaratan yang harus diajukan kepada Gubernur DKI Jakarta oleh PT. Jakarta Reality dalam hal telah diselesaikan pembangunan 
seluruh atau sebagian Cosmo Park Townhouse dengan merujuk ketentuan Pasal 39 UU Rumah Susun. Pada Penjelasan Pasal 39 ayat (1) UU Rumah Susun, diuraikan yang dimaksud bangunan yang laik adalah:

"berfungsinya seluruh atau sebagian bangunan rumah susun yang dapat menjamin dipenuhinya persyaratan tata bangunan dan keandalan bangunan rumah susun sesuai dengan fungsi yang ditetapkan dalam Izin Mendirikan Bangunan".

Kriteria suatu bangunan dapat dikatakan laik fungsi sebagaimana daitetapkan dalam Pasal 69 ayat (7) PP 36/2005 jo. Pasal 7 ayat (2) Permen PUPR 19/2018, yaitu:

a. prasarana dan sarana yang laik;

b. dilengkapi dengan dokumen pelaksanaan konstruksi;

c. gambar pelaksanaan pekerjaan sesuai dengan yang dilaksanakan (as built drawings);

d. pedoman pengoperasian dan pemeliharaan bangunan gedung;

e. peralatan serta perlengkapan mekanikal; dan

f. elektrikal bangunan gedung serta dokumen penyerahan hasil pekerjaan;

g. pernyataan dari pengawas atau Manajemen Konstruksi untuk bangunan gedung baru atau dari Pengkaji Teknis untuk bangunan gedung yang sudah ada (exsisting) bahwa bangunan gedung yang dibangun telah sesuai dengan IMB dan laik fungsi.

Penilaian kelaikan fungsi sebagaimana disyaratkan tersebut dilakukan oleh pengawas atau manajemen konstruksi untuk bangunan gedung baru atau pengkaji teknis untuk bangunan gedung yang sudah ada (existing) setelah dilakukan pemeriksaan kelaikan fungsi. Apabila pemeriksaan kelaikan fungsi sebagaimana menyatakan bangunan gedung tidak laik fungsi maka harus dilakukan pengubahsuaian (retrofitting). Hasil retrofitting diperiksa oleh pengawas atau manajemen konstruksi untuk bangunan gedung baru atau pengkaji teknis untuk bangunan gedung lama.

\section{Akta Pemisahan Satuan Rumah Susun}

Pasal 1 angka 2 PP Rumah Susun menjelaskan definisi dari Akta Pemisahan, yaitu:

"tanda bukti pemisahan rumah susun atas satuan-satuan rumah susun, bagian bersama, benda bersama dan tanah bersama dengan pertelaan yang 
jelas dalam bentuk gambar, uraian dan batas-batasnya dalam arah vertikal dan horizontal yang mengandung nilai perbandingan proporsional".

Sebelum perusahaan swasta memenuhi persyaratan administratif, persyaratan teknis, dan persyaratan ekologis dalam pembangunan rumah susun maka terlebih dahulu harus dilakukan pemisahan kesuluruhan rumah susun atas unit-unit atau satuan rumah susun, bagian bersama, benda bersama, dan tanah bersama sebagaimana diatur dalam Pasal 25 ayat (1) UU Rumah Susun. Pemisahan tersebut oleh pelaku pembangunan rumah susun nantinya dituangkan dalam bentuk gambar dan uraian, sehingga dapat memberikan kejelasan bagi calon pembeli atas: ${ }^{47}$

a. batas sarusun yang dapat digunakan secara terpisah untuk setiap pemilik;

b. batas dan uraian atas bagian bersama dan benda bersama yang menjadi hak setiap sarusun; dan

c. batas dan uraian tanah bersama dan besarnya bagian yang menjadi hak setiap sarusun.

Dalam hal pembangunan Cosmo Park Townhouse, maka PT. Jakarta Reality selaku pelaku pembangunan wajib mengajukan pengkonversian gambar dan uraian menjadi suatu tanda bukti bernama Akta Pemisahan yang disahkan oleh Gubernur DKI Jakarta sebagaimana diatur dengan 26 ayat (5) UU Rumah Susun. Konversi gambar dan uraian yang telah disahkan oleh Kepala Daerah menjadi Akta Pemisahan, kemudian didaftarkan oleh pelaku pembangunan pada Kantor Pertanahan setempat, dengan melampirkan : Sertipikat hak atas tanah, Ijin Layak Huni, Warkah-warkah lainnya yang diperlukan. Akta Pemisahan memiliki 2 fungsi utama sesuai ketentuan Pasal 26 ayat (2) UU Rumah Susun jo. Pasal 5 Peraturan Kepala Badan Pertanahan Nasional Nomor 2 Tahun 1989 Tentang Bentuk dan Tata Cara Pengisian serta Pendaftaran Akta Pemisahan Rumah Susun (selanjutnya disebut Permen 2/1989), yaitu:

i. menetapkan perhitungan Nilai Perbandingan Proporsional yang 
menggambarkan pembagian proporsi atas Hak Bersama Rumah Susun.

ii. dipergunakan sebagai dasar dalam penerbitan SHM sarusun atau SKBG sarusun, dan perjanjian pengikatan jual beli.

Penerbitan surat tanda bukti hak kepemilikan atas satuan rumah susun didapat dari Akta Pemisahan yang telah didaftarkan ke Kantor Pertanahan setempat, kemudian dari Akta Pemisahan tersebut setiap hak milik atas satuan rumah susun didaftar dalam 1 (satu) Buku Tanah, yaitu dokumen dalam bentuk daftar yang memuat data yuridis dan data fisik. Terhadap pembukuan hak milik atas satuan rumah susun tersebut maka dapat dilakukan penjilidan dokumendokumen menjadi satu bagian, yang terdiri atas: ${ }^{48}$

a. salinan dari buku tanah yang bersangkutan;

b. salinan surat ukur atas tanah bersama;

c. gambar denah satuan rumah susun yang bersangkutan.

Dokumen yang telah dijilid digunakan sebagai dasar penerbitan Sertifikat Hak Milik atas Satuan Rumah Susun susuai dengan Pasal 47 ayat (3) UU Rumah Susun jo. Pasal 7 ayat (4) Permen 4/1989.

\section{Analisis Surat Tanda Bukti Hak Pada Cosmo Park Townhouse Jakarta}

Pelaku pembangunan sebagaimana diatur dalam Pasal 29 ayat (1) UU Rumah Susun harus membangun rumah susun dan lingkungannya sesuai dengan rencana fungsi dan pemanfaatannya, maka apabila Thamrin City Mall yang mulai tahun 2007 dioperasikan sebagai fungsi non-hunian atau dalam hal ini yaitu perdagangan saja. Lalu pada tahun 2014 mulai dibangun kawasan hunian Cosmo Park Townhouse pada lantai 10, maka itu artinya kondisi arsitektur dan/atau keandalan bangunan Thamrin City Mall pada tahun 2007 tidak akan sama dengan kondisi pada tahun 2014. Sehingga dapat penulis simpulkan bahwa Izin Rencana Fungsi dan Pemanfaatan berserta Pengesahan Pertelaan yang sebelumya telah disahkan

${ }^{48}$ Pasal 7 Peraturan Kepala Badan Pertanahan Nasional Nomor 4 Tahun 1989 Tentang Bentuk dan Tata Cara Pembuatan Buku Tanah Serta Penerbitan Sertipikat Hak Milik Atas Satuan Rumah Susun. 
oleh Gubernur DKI Jakarta telah mengalami pengubahan. Pengubahan rencana fungsi dan pemanfaatan rumah susun tersebut tentu mengakibatkan pengubahan NPP sehingga pertelaannya pun harus mendapatkan pengesahan kembali dari Gubernur DKI Jakarta. Pengembang Cosmo Park Townhouse dalam hal ini PT. Jakarta Reality, harus mengajukan permohonan Izin Pengubahan Rencana Fungsi dan Pemanfaatan Rumah Susun berserta permohonan Pengesahan Pengubahan Pertelaan Rumah Susun dengan syarat-syarat sebagaimana diteteapkan dalam Pasal 31 ayat (6) UU Rumah Susun, sebagai berikut:

“pelaku pembangunan harus mengajukan alasan dan usulan pengubahan dengan melampirkan

a. gambar rencana tapak beserta pengubahannya;

b. gambar rencana arsitektur beserta pengubahannya;

c. gambar rencana struktur dan penghitungannya beserta pengubahannya;

d. gambar rencana yang menunjukkan dengan jelas bagian bersama, benda bersama, dan tanah bersama beserta pengubahannya; dan

e. gambar rencana utilitas umum dan instalasi serta perlengkapannya beserta pengubahannya".

Sehubungan dengan hal tersebut, salinan Keputusan Gubernur DKI Jakarta Tentang Pengesahan Perubahan Pertelaan Rumah Susun Cosmo Park Townhouse tidak tersedia dalam website Jaringan Informasi dan Informasi Hukum Pemerintah Provinsi DKI Jakarta (jdih.jakarta.go.id), sedangkan salinan Keputusan Gubernur DKI Jakarta yang mengatur perihal pengesahan pertelaan rumah susun di wilayah Provinsi DKI Jakrta tersedia dari tahun 2014 sampai dengan tahun 2019. Itu artinya, dapat penulis simpulkan per kondisi hari ini Perubahan Pertelaan Rumah Susun Cosmo Park Townhouse belum mendapat Pengesahan oleh Gubernur DKI Jakarta, yang berarti pula Pengubahan Rencana Fungsi dan Pemanfaatan Rumah Susunnya juga belum mendapatkan Izin oleh Gubernur DKI Jakarta. Kondisi demikian dapat disebabkan oleh persyaratan admnistratif dalam Pasal 28 UU Rumah Susun yang masih bermasalah, yaitu sertipikat hak atas tanah dan Izin Mendirikan Bangunan. Penulis memperkirakan penyebab utamanya bukan perihal hak atas tanah, namun terkait:

1) PT. Jakarta Reality belum dapat memenuhi persyaratan teknis permohonan Izin Pengubahan Rencana Fungsi dan Pemanfaatan Rumah Susun berserta 
permohonan Pengesahan Pengubahan Pertelaan Rumah Susun dalam Pasal 31 ayat (6) sebagaimana telah penulis sebutkan di atas;

2) IMB tidak dapat diterbitkan, dikarenakan PT. Jakarta Reality belum dapat menuntaskan kelengkapan permohonan IMB berupa : rencana teknis Bangunan Gedung, yang paling sedikit memuat : rencana arsitektur, rencana struktur, dan rencana utilitas; dan Hasil analisis mengenai dampak lingkungan bagi bangunan gedung yang akan menimbulkan dampak penting terhadap lingkungan sebagaimana diatur dalam Pasal 4 ayat (2) Permen PUPR 19/2018 jo. Pasal 15 ayat (1) PP 36/2005.

Tidak dipenuhinya syarat-syarat teknis dengan merujuk ketentuan Pasal 30 UU Rumah Susun akan menimbulkan akibat hukum bagi pemilik/penghuni lama dengan calon pembeli.

Pertama, bagi para pemilik/penghuni lama, Perubahan Pertelaan Rumah Susun Cosmo Park Townhouse yang belum mendapat Pengesahan oleh Gubernur DKI Jakarta dan Pengubahan Rencana Fungsi dan Pemanfaatan Rumah Susunnya yang juga belum mendapatkan Izin oleh Gubernur DKI Jakarta, akan mengakibatkan batas dari setiap sarusun, Bagian Bersama, Benda Bersama, dan Tanah Bersama berserta Uraian NPP tidak dapat diuraikan secara jelas. Jika demikian, terhadap pengelolaan rumah susun yang meliputi kegiatan operasional, pemeliharaan, dan perawatan terhadap hak-hak bersama dalam Pasal 56 ayat (1) UU Rumah Susun tidak dapat dilaksanakan.

Batas dari setiap sarusun, Bagian Bersama, Benda Bersama, dan Tanah Bersama berserta Uraian NPP wajib disertakan secara jelas dalam keterangan spasial yang ada di gambar dengan keadaan fisik pada Thamrin City Mall. Upaya ini penting agar tidak terjadi keluhan sebagaimana umumnya terjadi, yaitu bahwa luas satuan fisik satuan rumah susun lebih kecil daripada yang disajikan di gambar denah. Hal ini dapat terjadi mengingat unit yang digambarkan diukur sesuai dengan as atau titik tengah dari tembok atau kolom struktur suatu unit, sedangkan jika pemilik melakukan pengukuran di dalam ruangan yang didapat 
adalah luas net dari interior tersebut. ${ }^{49}$

Kedua, bagi calon pembeli, Pertelaan juga menjadi salah satu syarat untuk pengesahan dokumen lain untuk dapat diterbitkannya SHM Sarusun, yaitu Sertifikat Laik Fungsi dan Akta Pemisahan Rumah Susun. Tanpa adanya pertelaan, maka SHM Sarusun tidak dapat diterbitkan karena pertelaan merupakan satu kesatuan dari Buku Tanah Hak Milik Sarusun dan Gambar Denah Sarusun yang kesemuanya adalah unsur-unsur kumulatif dari SHM Sarusun sesuai yang diatur pada Pasal 47 ayat (3) UU Rumah Susun jo. Pasal 7 ayat (4) Permen 4/1989.

\section{Kesimpulan}

Pada Cosmo Park Townhouse, pemilik/penghuninya hanya berhak atas unit rumah yang dibeli/disewanya, dan tidak berhak menggunakan seluruh bangunan gedung bertingkat yang terdiri atas 10 (sepuluh) lantai, kemudian tidak berhak pula untuk mengambil manfaat bidang tanah di dalam lingkungan Thamrin City secara keseluruhan. Oleh karena itulah hak penguasaan atas tanah dan bangunan Cosmo Park Townhouse pastilah menggunakan Hak Milik Atas Satuan Rumah Susun (HMSRS) yang bersifat perseorangan dan terpisah menjadi Hak Bersama atas Bagian Bersama, Benda Bersama, dan Tanah Bersama.

Per kondisi hari ini Perubahan Pertelaan Rumah Susun Cosmo Park Townhouse belum mendapat Pengesahan oleh Gubernur DKI Jakarta, yang berarti pula Pengubahan Rencana Fungsi dan Pemanfaatan Rumah Susunnya juga belum mendapatkan Izin oleh Gubernur DKI Jakarta. Sehingga terhadap unit rumah Cosmo Park Townhouse belum terbit surat tnda bukti haknya berupa Sertipikat Hak Milik Atas Satuan Rumah Susun (SHM Sarusun).

\section{Daftar Bacaan}

\section{Buku}

Adrian Sutedi, Hukum Rumah Susun Dan Apartemen (Sinar Grafika 2010).

\footnotetext{
${ }^{49}$ Adrian Sutedi. Op.Cit.[143].
} 
Oloan Sitorus, Kondominium Dan Permasalahannya (Mitra Kebijakan Tanah Indonesia 1998).

Ridwan Halim, Sari Hukum Hak Milik, Kondominium Dan Rumah Susun (Puncak Karma Penerbit Buku Berguna 1990).

Satjipto Rahardjo, Ilmu Hukum (Citra Aditya Bakti 2000).

Urip Santoso I, Hukum Perumahan (Kencana 2014).

Urip Santoso II, Hak Atas Tanah, Hak Pengelolaan, Dan Hak Milik Atas Satuan Rumah Susun (Kencana 2017).

Urip Santoso III, Buku Ajar Hukum Pengadaan Dan Pendaftaran Hak Atas Tanah (Revka Petra Media 2018).

Urip Santoso IV, Hukum Agraria: Kajian Komperehensif, Cetakan Ke-6 (Kencana 2013).

\section{Jurnal}

J. Andy Hartanto, 'Kepemilikan Hak Milik Atas Satuan Rumah Susun' (2013) 02 Jurnal Rechtens Universitas Islam Jember.

\section{Tesis}

Erny Suciapriyanti, Tinjauan Yuridis Pemberlakuan Undang-Undang Nomor 20 Tahun 2011 Tentang Rumah Susun Terhadap Semua Bangunan Bertingkat, Skripsi (Universitas Sumatera Utara 2012).

Felicia Melissa Yuanita, Keabsahan Condomonium Hotel Yang Dibangun di Atas Tanah Hak Guna Bangunan Atas Tanah Hak Milik Dari Perspektif UndangUndang Nomor 20 Tahun 2011 Tentang Rumah Susun, Tesis (Fakultas Hukum Universitas Airlangga 2014).

\section{Lembaga}

Badan Pusat Statistik Provinsi DKI Jakarta, Jakarta Dalam Angka (2019).

\section{Laman}

Aini Putri Wulandari, 'Melihat Dari Dekat Rumah-Rumah Di Atas Gedung Thamrin City' (CNN Indonesia, 2019) <https://www.cnnindonesia.com/ nasional/20190626162138-20-406652/ melihat-dari-dekat-rumah-rumah-diatas-gedung-thamrin-city> accessed 17 August 2019. 
Aswin Saputra, 'Jumlah Rumah Susun Di DKI Jakarta' (2018) <https:// lokadata.beritagar.id/chart/ preview/jumlah-rumah-susun-di-dkijakarta-1534228588> accessed 18 August 2019.

Mahanik, 'Thamrin City Mall' (2012) <http://infopromodiskon.com/mall/ profile/thamrin-city-mall/> accessed 18 August 2019.

Prima Fauziah, 'Cosmo Park Thamrin City' (The Condotel, 2019) <http:// thecondotel.com/id/18/Cosmo_Park_Thamrin_City> accessed 17 August 2019 .

Triyono, 'Company Profile The Jakarta Propertindo' (Thamrin Residence, 2015) <https://www.thamrinresidence.wordpess.com/company-profile/> accessed 18 August 2019.

\section{Perundang-undangan}

Undang-Undang Dasar Negara Republik Indoenesia Tahun 1945.

Undang-Undang Nomor 5 Tahun 1960 Tentang Peraturan Dasar Pokok-Pokok Agraria (Lembaran Negara Republik Indonesia Tahun 1960 Nomor 104, Tambahan Lembaran Negara Republik Indonesia Nomor 2043).

Undang-Undang Nomor 1 Tahun 2011 Tentang Perumahan dan Kawasan Permukiman (Lembaran Negara Republik Indonesia Tahun 2011 Nomor 7, Tambahan Lembaran Negara Republik Indonesia Nomor 5188).

Undang-Undang Nomor 20 Tahun 2011 Tentang Rumah Susun (Lembaran Negara Republik Indonesia Tahun 2011 Nomor 108, Tambahan Lembaran Negara Republik Indonesia Nomor 5252).

Peraturan Pemerintah Nomor 4 Tahun 1988 Tentang Rumah Susun (Lembaran Negara Republik Indonesia Tahun 1988 Nomor 7).

Peraturan Pemerintah Nomor 40 Tahun 1996 Tentang Hak Guna Usaha, Hak Guna Bangunan, dan Hak Pakai Atas Tanah (Lembaran Negara Republik Indonesia Tahun 1996 Nomor 58, Tambahan Lembaran Negara Republik Indonesia Nomor 3643).

Peraturan Kepala Badan Pertanahan Nasional Nomor 2 Tahun 1989 Tentang Bentuk dan Tata Cara Pengisian serta Pendaftaran Akta Pemisahan Rumah Susun.

Peraturan Kepala Badan Pertanahan Nasional Nomor 4 Tahun 1989 Tentang 
Bentuk dan Tata Cara Pembuatan Buku Tanah Serta Penerbitan Sertipikat Hak Milik Atas Satuan Rumah Susun.

Peraturan Menteri Pekerjaan Umum dan Perumahan Rakyat Republik Indonesia Nomor 19/Prt/M/2018 Tentang Penyelenggaraan Izin Mendirikan Bangunan Gedung dan Sertifikat Laik Fungsi Bangunan Gedung Melalui Pelayanan Perizinan Berusaha Terintegrasi Secara Elektronik.

How to cite: Malikuz Zahir, 'Tinjauan Yuridis Pembangunan Perumahan Di Atas Gedung Bertingkat (Studi Kasus Cosmo Park Townhouse Jakarta)' (2020) Vol. 3 No. 3 Notaire. 
380 | Malikuz Zahir: Tinjauan Yuridis Pembangunan...

--Halaman ini sengaja dikosongkan-- 